\title{
Interpretation Of Phonetic Interference As A Linguistic Phenomenon In Uzbek And English
}

\author{
Abdivaitova Sevarakhon Bakhtiyorjon Qizi \\ Teacher Of English Department Of Tashkent Institute Of Irrigation And Agricultural \\ Mechanization Engineers, Tashkent, Uzbekistan
}

Journal Website: http://usajournalshub.c om/index,php/tajssei

Copyright: Original content from this work may be used under the terms of the creative commons attributes 4.0 licence.

\section{ABSTRACT}

This article focuses on the phonetic interference of word stress in English and Uzbek. It examines the phonetic interference of word stress resulting from the interaction of comparable languages.

\section{KEYWORDS}

Interference, stress, diphthong, monoftong, syllable, pronunciation, language porosity, multi-syllable word.

\section{INTRODUCTION}

In Uzbekistan, a lot of research has been done on the scientific study of science, in particular, the phonetics department of linguistics. Scientific research conducted by well-known scholars and published textbooks and manuals serve as a guide for deep learning of foreign languages in our country. However, there are still challenges in applying scientific advances to foreign language teaching practices. Today, in world linguistics, research is being conducted on phonetic units - speech sounds, syllables, accents, intonation, and their specific features in speech. The scientific study of the phonetic features of the accent is also a topical issue. 
This phenomenon is one of the current problems of linguistics today, due to the fact that scholars have different views on the specifics of linguistic interference and the mechanisms of movement of languages in different systems in the minds of linguists.

Among these types of interference, phonetic interference is especially important because phonetics (phonology) is the first level of language, and learning a second language begins with mastering the same area of language. This linguistic phenomenon has been studied by many linguists.

They are called sound interference, also phonetic or phonological. Professor $M$. Djusupov proposes to call this phenomenon phonetic-phonological interference. According to N.Radjabov, linguistic interference as a product of the imbalance between the studied foreign language and the native language should be described as a set of factors that negatively affect the learning process.

Another reason for phonetic interference can be understood not only as differences in the sound system of the native language and the foreign languages studied, but also as a result of the combination of groups of sounds represented by the same letters in the text. This situation was studied by N. Radjabov on the example of vowels of English and Uzbek languages, which explained the factors that lead to spelling interference of vowels.

\section{MATERIALS AND METHODS}

Many of the problems that are constantly being addressed in the field of foreign language teaching are related to the use of phonetics, especially lexical stress. In English, word stress is a means of determining the pronunciation of more than $90 \%$ of words and their syntactic and semantic accuracy. Linguistic differences between languages lead to students misinterpreting lexical stress in English. That's why Uzbek students often use English words in the last syllable. Such an error should not be overlooked. This is because it disrupts the communication process and leads to uncertainty. Therefore, it is important to teach lexical emphasis to Uzbek students, as well as to language learners whose native language is different from English in terms of accent.

While phonemes can distinguish one word from another, accents also determine the meaning of words. As mentioned in the first chapter, the acoustic signs that make up an accent are not the same in all languages. For example, native English speakers often use length, base tone, percussion, and high frequency at the same time. Linguists, on the other hand, sometimes use one or two of these factors, which impairs the quality of the accent. For example, Uzbek students tend to overlook factors that focus more on pitch. Not only sound education but his alertness and dedication too are most required.

There is a lot of work that needs to be done to teach and study the emphasis, and none of them can be overlooked and requires a serious, critical approach to the situation. Defective pronunciation simply leads to defective prosodic and intonational skills in foreign language learners. This can be frustrating for both the learner and the listener.

In recent days, foreign language educators have been focusing on forming an understanding of segment and supersegment units in light of these considerations. Therefore, teachers need to know the prosody and intonation of the language being taught, the prosodic and intonation errors that can be 
made, and the root causes of such errors. In some cases, when it comes to the emphasis on English and Uzbek, the focus is on finding the right place for the emphasis.

However, errors are not reflected in the correct position of the stress, but in the full reflection of the stress. When left unmanaged, they can be left astray and lose the right path. This means that professionals need to know how to create a perfect accent in English and develop this skill in students.

\section{RESULT AND DISCUSSION}

We seem to have found the answer to the question of when English learners can speak fluently with confidence. When they have a better understanding of lexical stress, of course. This is because through emphasis, students shape speech not only phonetically but also stylistically and semantically. Through emphasis, they learn to control the rhythm of the tone of speech and speech. If the topic of word stress is ignored, or lexical stress lessons are not organized as desired, students will continue to have speech impediments or misunderstandings in communication with native English speakers.

Comparative study of Uzbek and English accents determines the formation of interlinguistic phonetic interference. You can also identify errors that occur here. That is, phonetic interference is currently the most pressing issue in the perfect study of English. Overcoming these problems requires a scientific study of the linguistic factors that contribute to the phonetic interference of word stress in English and Uzbek. In our opinion, it is necessary to distinguish three types of linguistic problemss that lead to phonetic interference of word stress in the compared languages: 1) the problem of stressing both parts of the diphthong, 2) the problem of each of the multi-syllable words the mistake of pronouncing a syllable with a main accent, 3) the mistake of pronouncing a word that cannot be stressed with an accent.

We know that there are 20 different vowels in the process of learning English. Of the 20 vowel sounds in English, 12 are monophthongs and 8 are diphthongs. Of these, diphthongs make it more difficult to learn a language.

Diphthongs are single vowel sounds that consist of a combination of two vowel sounds and are pronounced in a single syllable. In diphthongs, the first vowel sound is pronounced louder than the second. However, it should be noted that both sounds are pronounced in the same syllable. Because for Uzbek students studying English, diphthongs are completely unfamiliar sounds. Therefore, diphthongs often do not pronounce the second sound, they only pronounce the first sound. For example, day [dei], play [plei], came [keim], take [teik], straight [streit], complain [kəm'plein], translation [træns'leifən],

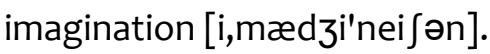

Uzbek students often pronounce diphthongs in length, emphasizing both parts, that is, pronouncing both sounds as separate sounds. For example, go [gəu] o'rniga [gə:u:], toy [toi] - [to:i:], home [həum] - [hə:u:m], road [rəud] [rə:u:d], robe [rəub] - [rə:u:b], goat [gəut] [gə:u:t], oak [əuk] - [ə:u:k], post [pəust] -

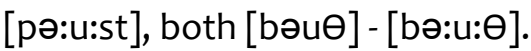

Another factor that causes phonetic interference in word stress in English and Uzbek is the pronunciation of each syllable in a multi-syllable word with a main accent. When we talk about the stress of a word, we understand that the stress falls on the vowel and makes it more pronounced. 
If the emphasis is placed incorrectly on the words, it will be difficult for native English speakers to understand. Another factor that causes phonetic interference in word stress in English and Uzbek is the mispronunciation of unstressed words. Grammatically, nouns, verbs, adjectives, and adverbs are stressed in English. However, some words in English are not stressed, which leads to interference in Uzbek speakers of English. That is, they often make a mistake in pronouncing words such as articles, prepositions, and rhymes that are not stressed.

\section{CONCLUSION}

To sum up, differences in the phonetic features of accent in English and Uzbek cause interference in the English speech of Uzbek speakers. The main reason for phonetic interference is that the sounds of the native language and the foreign languages studied in the sound system, as well as in both languages, are represented by the same letters in the text. The scientific study of interference in linguistics, especially the precise knowledge of the typology of phonetic interference and the study of the classification of its types, is important for students of the Uzbek audience. This is because Uzbek students often overlook the factors that make them focus on tattoos. This affects not only the emphasis, but also the process of understanding it.

\section{REFERENCES}

1. Radjabov N.N. A phonological comparison of the vocal system in English and Uzbek: (PhD) diss. avtoref. - Tashkent, 2018. - 48 p.

2. Jusupov M. Sound systems of Russian and Kazakh languages. Syllable. Interference. Pronunciation training. - T .: Fan, 1991 .-162-170 p.
3. Weinreich $U$. Language contacts. Research status and problems. Kiev .: Nauka, 1979, - 264 p.

4. Shcherba L.V. Language system and speech activity. - L .: Nauka, 1974.428 p.

5. Karlinsky A.E. Experimental study of lexical interference for applied purposes. Alma-Ata .: Galym, 1989, p. 42. 